\title{
From legacy to novel: vidian neurectomy and eustachian tube balloon dilatation in modern ENT practice
}

The last issue for 2016 represents the healthy state of Australasian otolaryngology research. This issue presents two excellent examples of secondary research efforts to tackle controversial topics. The role of vidian neurectomy is addressed by Marshak et al. who demonstrate a body of evidence for its role in both mixed and non-allergic rhinitis. ${ }^{1}$ The concerns that many have about its potential for adverse events are not as high as anecdotally stated. Although the other review, on balloon dilatation for eustachian tube dysfunction, presents evidence from a more nascent field of surgical experience, it is still supported by nine studies and more than seven hundred patients. ${ }^{2}$ The authors demonstrate that there is clearly more than a placebo effect, as both symptoms and tympanometry findings are affected by balloon procedures. There is obviously a need to separate the effects of surgery from the natural history of the condition and the influence of other interventions, but it's an exciting area of research on a very common condition.

Australia is fortunate to have great neuro-otology centres, and they share their experience. Prof Friedland's group from Perth report their work in tackling chronic suppurative otitis media, and describe a staged approach to achieve both a dry ear and enable subsequent cochlear implantation and hearing restoration. ${ }^{3}$ The role of an experienced lateral skull base team in the management of carotid aneurysms is reviewed by Mukherjee et al. as they critique the outcomes of both open and endovascular approaches in a small series of patients requiring intervention. ${ }^{4}$ This skull base experience is also shared by the Brisbane group as they present their approach to imaging of the anterior skull base. Such local expertise is essential as it blends training, an evidence-based approach, with the availability of local resources in Australia into a practical algorithm.

Australian surgeons lead the world in our experience with melanoma, cutaneous squamous cell carcinoma and metastatic parotid disease. The experience of Park et al. further validates the current practice of adding at least a selective neck dissection in the management of metastatic parotid disease. ${ }^{5}$ With a 17 per cent rate of occult disease in the node-negative neck, the current approach appears to be supported. They also highlight the 'at risk' groups with immunosuppression, in which a more aggressive treatment strategy might be appropriate. Similarly, the Westmead group review the role of wide midline neck dissection to improve the outcomes of thyroglossal duct management. ${ }^{6}$ They present a smaller series, helping to define the anatomy and their clinical experience in patients with prior treatment.

This issue is full with original research from Australasian researchers. I encourage all otolaryngologists to consider The Journal of Laryngology \& Otology as the destination for publication. The Journal has recently moved forward in impact factor and is now a Q2 journal within the otolaryngology group. Quality research efforts from Australia are almost certainly a contributing factor to this success.

RICHARD HARVEY Editor

Australian Supplement of The Journal of Laryngology \& Otology

\section{References}

1 Marshak T, Yun WK, Hazout C, Sacks R, Harvey RJ. A systematic review of the evidence base for vidian neurectomy in managing rhinitis. $J$ Laryngol Otol 2016;130(suppl 4):S7-28

2 Hwang SY, Kok S, Walton J. Balloon dilation for eustachian tube dysfunction: systematic review. J Laryngol Otol 2016;130(suppl 4):S2-6

3 Casserly P, Friedland PL, Atlas MD. The role of subtotal petrosectomy in cochlear implantation. J Laryngol Otol 2016; 130(suppl 4):S35-40

4 Mukherjee P, Huilgol R, Graham A, Fagan P. Open and endovascular repair of aneurysms affecting the distal extracranial internal carotid artery: case series. J Laryngol Otol 2016;130(suppl 4): S29-34

5 Park SW, Eade T, Pang L, Wignall A, Veivers D. Role of neck dissection in metastatic squamous cell carcinoma to the parotid gland. J Laryngol Otol 2016;130(suppl 4):S54-9

6 O'Neil LM, Gunaratne DA, Cheng A, Riffat F. Wide anterior neck dissection for management of recurrent thyroglossal duct cysts in adults. J Laryngol Otol 2016;130(suppl 4):S41-4 